\title{
Assessment of Antimicrobial Properties of Cow Urine Distillates
}

\author{
A.J. Manjramkar, V.V. Deshmukh, R.N. Waghamare* and M.S. Vaidya \\ Department of Veterinary Public Health, College of Veterinary and Animal Sciences, \\ Parbhani, Maharashtra 431402 India \\ *Corresponding author
}

\section{Ke y w o r d s \\ Cow urine distillate, Antimicrobial, Phenol coefficient, Agar well diffusion test}

Article Info

Accepted:

22 July 2019

Available Online:

10 August 2019

\section{A B S T R A C T}

The present study was planned to assess antimicrobial properties of cow urine distillate. A total of six cow urine distillates comprising of five commercially available and one prepared in the laboratory were used in present study. All these six cow urine distillates were coded as $\mathrm{C} 1, \mathrm{C} 2, \mathrm{C} 3, \mathrm{C} 4, \mathrm{C} 5$ and $\mathrm{P}$. The phenol coefficient of all six cow urine distillates was evaluated against $S$. aureus and $E$. coli. The phenol coefficients of $\mathrm{C} 4$ and C5 against $S$. aureus and E. coli were $0.04 \pm 0.00$ and $0.03 \pm 0.00$ respectively. Agar well diffusion technique was utilized for the in-vitro antimicrobial property of the cow urine distillate against $S$. aureus and E. coli. The C4 distillate showed maximum zone of inhibition $(18 \pm 0.45 \mathrm{~mm})$ against $S$. aureus and $(15.21 \pm 0.82 \mathrm{~mm})$ against $E$. coli. The zones of inhibition of C5 distillate against $S$. aureus and E. coli were $10.51 \pm 0.44 \mathrm{~mm}$ and $15.21 \pm 1.27 \mathrm{~mm}$ respectively. The distillates C3, C4 and C5 were assessed for efficacy of them for their antimicrobial activity in three randomly selected poultry slaughter shops on platform used for poultry slaughter. The observations were made by calculating TVC, $S$. aureus and E. coli counts before and after treatment of cow urine distillates. It was interesting to note that all three distillate (C3, C4 and C5) showed highly significant ( $\mathrm{p}<$ 0.01 ) lower TVC counts post treatment. Comparison of mean S. aureus counts of C3, C4 and C5 groups before and after treatment showed that C4 and C5 distillates highly significant $(\mathrm{p}<0.01)$ lower the $S$. aureus counts. However, the effect of C3 on S. aureus counts was not seen. The $\mathrm{C} 3$ and $\mathrm{C} 4$ cow urine distillates exhibited highly significant $(\mathrm{p}<0.01)$ reduction in $E$. coli counts whereas, C5 distillate significantly $(\mathrm{p}<0.05)$ reduced the $E$. coli counts.

\section{Introduction}

Indian cow urine is of medicinal value as per ancient Ayurveda. The literature like Charaka Samhita, Sushruta Samhita, Atharva Veda etc. narrate details of its use. A lot of research has been conducted in Cow Urine Treatment and Research Centre, Indore. It has been reported that cow urine is capable of curing many diseases like blood pressure, asthma, thyroid etc. In Ayurveda, cow urine used almost as broad spectrum antibiotic as therapeutic agent. It is also used in agriculture and sericulture. Cow urine is used as disinfectant and for purification. It has approximate shelf life of five years (Sai Kishore et al., 2015). 
A study of cow urine distillate against clinical pathogens like Bacillus subtilis, Pseudomonas aeruginosa, Klebsiella pneumoniae, Salmonella typhi and fungus Aspergillus niger and Aspergillus flavus showed antimicrobial activity. Antimicrobial activity of cow urine distillate was tested using agar well method against microbes like E. coli, S. aureus, Klebsiella pneumoniae. Comparatively fresh cow urine was found to be more active than its distillate. The activity of fresh cow urine was comparable with ofloxacin. Cow urine distillate with extracts of herbs like Azadirachta indica showed antimicrobial activity against multidrug resistant clinical isolates of E. coli and Klebsiella pneumoniae (Kaushik et al., 2016).

Various infectious agents of public health significance survive in the environment like E. coli, S. aureus, Klebsiella. The infectious agents are shed in excretions or secretions of animals or present in production like meat and remain viable for long periods in the environment. In poultry slaughter house building, water, utensils, personnels, platform etc. can be source of infectious agents in food chain. Disinfection is an essential part of hygiene control programme. Chemical disinfectants like sodium hypochlorite or heated strong solution of sodium hydroxide are being used. The most important decision in disinfection programme is the choice of disinfectant is based on superiority of particular disinfectant for the circumstances in which it is being used and infectious agents. To ensure success disinfection requires planning and thorough implementation. Many chemicals used as disinfectants are corrosive, toxic or hazardous. Selection of disinfectant requires knowledge of antimicrobial spectrum, cost, availability and safety (Koleci et al., 2007).

For antimicrobial pharmaceutical composition of cow urine distillate granted U.S. patent. The patent was granted for bioenhancing property of cow urine distillate for various antibiotics (Khanuja et al., 2002).

Many herbal extracts in cow urine distillates have been found to be effective as antimicrobials. Rajapandiyan et al., (2011) used cow urine extract of Azadirachta indica as a novel controlling agent towards clinically significant antimicrobial. Poornima et al., (2012) used cow urine extracts of Polyathalia longifolia for estimation of antimicrobial activity. Farida et al., (2014) used Shatavari, tulsi, neem, guduchi cow urine extracts to study their antimicrobial activity on human pathogens.

The herbal disinfectants was found to be effective in controlling microbes, noncorrosive and safe to use on most surfaces, environment friendly and biodegradable. (Mandavgane et al., 2005) developed cow urine based disinfectant. They used neem, ritha, pine oil extracts in cow urine.

The slaughter house is a critical stage in meat production as it presents opportunities for contamination. The manner in which poultry is slaughtered, eviscerated, dressed and stored can affect growth of pathogens and potential contamination of meat. The lack of hygiene practices by plant workers can also contaminate carcasses. Slaughter house is considered as a vehicle for human food-borne diseases. Although spectrum of meat-borne diseases of public health importance has change due to improved production system continuation of problem is well illustrated (Zailani et al., 2016).

Keeping these facts in view, the present study was planned to study antimicrobial properties of commercially available cow urine distillates against E. coli and Staphylococcus aureus and to compare of efficacy of commercially and locally available cow urine distillates as disinfectant. 


\section{Materials and Methods}

Cow urine distillate: A total of five commercially available cow urine distillates were procured from the market and cow urine distillate was also prepared in the laboratory. All these six cow urine distillates were given code as $\mathrm{C} 1, \mathrm{C} 2, \mathrm{C} 3, \mathrm{C} 4, \mathrm{C} 5$ and $\mathrm{P}$, respectively.

\section{Phenol coefficient method}

Phenol coefficient was used for evaluation of disinfectant property of cow urine distillates using $S$. aureus (MTCC96) and E. coli (MTCC1652) cultures procured from Department of Veterinary Public Health and Epidemiology, Nagpur Veterinary College, Nagpur. The method used was United States FDA method of testing antiseptics and disinfectants described by Ruehle and Brewer, (1931). The highest dilution of that kills bacteria in $10 \mathrm{~min}$ was considered positive for calculation of phenol coefficient. Phenol coefficient was calculated by the formula,

Phenol coefficient of test compound=

Dilution of test disinfectant

Dilution of Dilution of phenol

\section{Antimicrobial activity}

Antimicrobial activity of cow urine distillates were evaluated by method described by Ahuja et al., (2012). The test organisms used in the study were Staphylococcus aureus (MTCC96) and Escherichia coli (MTCC1652) cultures procured from Department of Veterinary Public Health and Epidemiology, Nagpur Veterinary College, Nagpur. The cultures were maintained at $4^{\circ} \mathrm{C}$ on nutrient agar (Himedia laboratories, Mumbai). The antibacterial activity of all cow urine distillates were performed using Agar Well Diffusion method.

\section{Poultry slaughter shop}

A total of 3 poultry slaughter houses were randomly selected for evaluation of antimicrobial property of cow urine distillates.

\section{Swab collection from poultry slaughter} house

Sterile swab samples were collected from selected poultry meat shops platform before and after cow urine distillate treatment by following standard procedures Patterson (1971).

\section{Total Viable Count (TVC)}

The TVC were determined by using Standard Plate Count Agar as per method described in AOAC (1997)

\section{Isolation of organisms}

Isolation and enumeration of Staphylococcus aureus, E. coli was done by using selective media as per method described in BAM (1998).

\section{Recording and handling of data}

The phenol coefficient of cow urine distillates were recorded and their means were compared amongst groups using CRD. The mean zones of inhibition of $S$. aureus and $E$. coli were calculated. The zones of inhibition were recorded as $(\varnothing \mathrm{mm})$. The mean zones of inhibition were compared amongst group using CRD. The data were analysed using WASP - Web Agri Stat Package 2.0 developed by ICAR Research complex for Goa.

\section{Results and Discussion}

\section{Cow urine distillates}

A total of five commercially available cow urine distillates were procured from the 
market. Cow urine distillate was also prepared in the laboratory. All these six cow urine distillates were given coded as C1, C2, C3, $\mathrm{C} 4$ and $\mathrm{C} 5$ whereas the laboratory prepared cow urine distillate was given code as $\mathrm{P}$. Cow urine distillates $\mathrm{C} 2, \mathrm{C} 3, \mathrm{C} 4$ and $\mathrm{C} 5$ contains extracts of various herbs in cow urine. A total of eight replicates of each cow urine distillate were made consisted of 48 samples for analysis. The details of sample collection are given in Table 1. Antimicrobial properties were tested including phenol coefficient of all 48 samples.

\section{Poultry slaughter shop}

After quality assessment, the cow urine distillates were evaluated for their efficiency in poultry slaughter shop for disinfection. The cow urine distillates showing antimicrobial property upon in-vitro analysis were used for efficacy assessment. A total of 3 poultry slaughter house were randomly selected from Parbhani city. All the poultry slaughter shop were given code names as S1, S2 and S3. The details of poultry slaughter shop used are given in Table 2. A total of three cow urine distillates were tested during experiment. A total of six replicates of each cow urine distillate were made. The cow urine distillates were analysed before and after treatment of platform in relation to total viable counts, total Staphylococcal and E. Coli counts.

\section{Estimation of Phenol Coefficient}

Varley and Reddish (1936) recommended Phenol coefficient test developed by Rideal and Walker in 1903 adopted by U.S. FDA for evaluation of disinfectants using $S$. aureus and $E$. coli with a exposure time of 5 minutes interval upto 20 minutes. In India, Food Safety and Standard Regulations,(2011) stipulated microbial standards for poultry slaughter houses (Pradeep Kumar et al., 2014). Various workers developed cow urine based disinfectants. Mandavgane et al., (2005) used neem, tulsi, ritha and pine oil for development of cow urine based disinfectant. The phenol coefficient of it against S. typhi and $S$. aureus. The cow urine based disinfectant was found to be useful in cleaning surfaces.

In present study all six cow urine distillates were evaluated against $S$. aureus and E. coli for a period of 20 minutes.

\section{Against Staphylococcus aureus}

All six cow urine distillates were evaluated for estimation of phenol coefficient against $S$. aureus. The results are shown in Table 3. It is interesting to note that cow urine distillate $\mathrm{C} 4$ and $\mathrm{C} 5$ could only inactivate $S$. aureus within 5 minutes at 1:5 concentrations. The phenol coefficients recorded of $\mathrm{C} 4$ and $\mathrm{C} 5$ are $0.04 \pm$ 0.00 and $0.03 \pm 0.00$ respectively. The comparison of them revealed non-significant effect amongst them. Earlier, Randhawa (2010) reported use of cow urine distillate as bioenhancer of antimicrobial property of drugs. The cow urine disinfectants are prepared by using various herbal extracts were found to be effective against $S$. aureus (Mandavgane et al., 2005).

In present study effectiveness of cow urine distillate C4 and C5 against S. aureus (Table 3) may be due to its bioenhancing property to boost antimicrobial activity of herbal extracts than other cow urine distillates as reported earlier.

\section{Against Escherichia coli}

The results of estimation of phenol coefficient of all cow urine distillates are given in Table 4. The cow urine distillates $\mathrm{C} 4$ and $\mathrm{C} 5$ showed phenol coefficients of $0.04 \pm 0.00$ and $0.03 \pm 0.00$ respectively against $E$. coli. The average phenol coefficients of both the 
disinfectants (C4 and C5) are found to be at par with each other. The other cow urine distillates $\mathrm{C} 1, \mathrm{C} 2, \mathrm{C} 3$ and $\mathrm{P}$ were found to be ineffective against $E$. coli.

The efficacy of disinfectant used in food industry against $E$. coli by using phenol coefficient test was compared by Taylor et al., (1999). In present study also phenol coefficient test has been successfully exploited to evaluate cow urine distillates against E. coli.

\section{In-vitro antimicrobial analysis of cow urine distillates}

Cow urine is having antimicrobial property in addition to its disinfectant property (Chauhan and Dhama, 2010). The antimicrobial activity is due to presence of various components like urea, phenol, carboxylic acids, calcium, manganese in addition to certain amino acids and urinary peptides (Gulhane et al., 2017).

Sathasivam et al., (2010) analysed antimicrobial activity of cow urine distillate in-vitro against clinical pathogenic microorganism by using agar well diffusion test. Goswami and Kaushik (2017) also successfully used disc diffusion assay for comparing cow urine distillate with antibiotics.

In present study in-vitro antimicrobial analysis of all six cow urine distillates was made. The results are given in Table 5. The zones of inhibition were recorded against $S$. aureus and E. coli. The mean zones of inhibition were compared between and amongst groups. The cow urine distillates $\mathrm{C} 1$, $\mathrm{C} 2$ and $\mathrm{P}$ did not show any antimicrobial activity against $S$. aureus and $E$. coli.

The distillate $\mathrm{C} 4$ showed maximum zone of inhibition against $S$. aureus (18.55 \pm 0.45 $\mathrm{mm})$ and $E$. coli $(15.21 \pm 0.82 \mathrm{~mm})$. The C5 distillate showed zone of inhibition of $10.51 \pm$ $0.44 \mathrm{~mm}$ against $S$. aureus and $15.21 \pm 1.27$ $\mathrm{mm}$ against $E$. coli. Statistically $\mathrm{C} 4$ cow urine distillate showed highly significant $(\mathrm{p}<0.01)$ increased zone of inhibition against $S$. aureus and significant $(\mathrm{p}<0.05)$ increase against $E$. coli. The cow urine distillate C5 showed significant $(\mathrm{p}<0.05)$ increase against both $S$. aureus and $E$. coli.

Sathasivam et al., (2010) reported zone of inhibition of $7.6 \pm 0.04 \mathrm{~mm}$ of cow urine distillate against B. Subtilis and $13.6 \pm 0.07$ $\mathrm{mm}$ against $S$. typhi. Kekuda et al., (2010) also used disc diffusion method for evaluation of antimicrobial activity of cow urine distillate using $S$. aureus and E. coli. The zone of inhibition observed against $S$. aureus was $16 \mathrm{~mm}$ and $14 \mathrm{~mm}$ against E. coli. Rajapandiyan et al., (2011) used cow urine distillate with herbal preparation for evaluation of antimicrobial activity using $E$. coli by disc diffusion method. A zone of inhibition of $12.68 \mathrm{~mm}$ was observed against E. coli.

The results of present study are on the similar lines as reported earlier. However, absence of antimicrobial activity in cow urine distillates $\mathrm{C} 1, \mathrm{C} 2$ and $\mathrm{P}$ might be due to absence of herbal extracts in the same. Whereas in cow urine distillate $\mathrm{C} 3, \mathrm{C} 4$ and $\mathrm{C} 5$ the bioenhancer activity of herbal extracts and other additives is clearly evident. Randhawa (2010) also reported bioenhancer property of cow urine distillate in antimicrobial properties. The results of present study are in confirmation of the same.

\section{In-vivo Antimicrobial quality assessment of cow urine distillates}

Khanuja et al., (2002) successfully filed U.S. patent of cow urine distillate. The invention relates to novel use of cow urine distillate as activity enhancer of antimicrobial agents. 
Poultry slaughter house is an important source of entry of bacteria of public health significance in food chain. The meat contact surfaces of slaughter house are important and needs hygienic maintenance (Zailani et al., 2016). In India retail meat shops are important source of bacteria of public health significance. The Food Safety and Standards Regulations, (2011) requires hygienic maintenance at poultry slaughter houses (Pradeep Kumar et al., 2014). The Food industry requires use of disinfectants which are hazard free for maintenance of public health (Taylor et al., 1999). Various methods are used for microbiological quality assessment of surfaces like swab, rinse, agar contact and direct plating. However, swab method was found to be useful in quality assessment of surfaces (Patterson, 1971).

In present study, cow urine distillates $\mathrm{C} 3, \mathrm{C} 4$ and $\mathrm{C} 5$ which were found to be having antimicrobial and disinfectant property used in poultry slaughter shop for quality assessment of platform.

\section{Evaluation of TVC counts}

Estimation of TVC counts of platform used for poultry slaughter before and after use of disinfectant gives an idea of efficacy of disinfectant and antimicrobial agent
(Patterson, 1971; Pradeep Kumar, 2014).

In present study, TVC counts estimation has been successfully exploited for assessment of efficacy of cow urine distillates. The results are given in Table 6.

Perusal of Table 6 clearly indicate that highly significant reduction in TVC counts of platform was found. After treatment in all three cow urine distillates (C3, C4 and C5) when compared to pre-treatment. The reduction in TVC counts of $\mathrm{C} 3$ was $7.49 \pm$ $0.03 \log _{10} \mathrm{cfu} / \mathrm{cm}^{2}$ from $7.62 \pm 0.03 \log _{10}$ $\mathrm{cfu} / \mathrm{cm}^{2}$, in $\mathrm{C} 4$ it was $7.23 \pm 0.04 \log _{10}$ $\mathrm{cfu} / \mathrm{cm}^{2}$ from $7.62 \pm 0.002 \log _{10} \mathrm{cfu} / \mathrm{cm}^{2}$ and $7.33 \pm 0.03 \log _{10} \mathrm{cfu} / \mathrm{cm}^{2}$ from $7.62 \pm 0.03$ $\log _{10} \mathrm{cfu} / \mathrm{cm}^{2}$ in $\mathrm{C} 5$.

Earlier Chauhan and Dhama, (2010) described use of cow urine distillate for antimicrobial activities. Diversified uses of cow urine distillates as antimicrobial and disinfectant have also been reported by Mohanty et al., (2014). Use of cow urine in purification and detoxification processes was also been reported by Gulhane et al., (2017). In present study reduction in total TVC counts of platform used for poultry slaughter indicate possibility of using cow urine distillate based disinfectants for maintainence of public health.

Table.1 Details of cow urine distillates used in the experiment

\begin{tabular}{|c|c|c|c|c|}
\hline Sr. No. & Code & Source & Contents & No. of Replicates \\
\hline $\mathbf{1}$ & C1 & Commercial & Cow urine distillate & 8 \\
\hline $\mathbf{2}$ & C 2 & Commercial & Gulvel goarka & 8 \\
\hline $\mathbf{3}$ & C3 & Commercial & Neem gomutra & 8 \\
\hline $\mathbf{4}$ & C4 & Commercial & Neem gomutra & 8 \\
\hline $\mathbf{5}$ & C5 & Commercial & Lemon grass, & 8 \\
\hline $\mathbf{6}$ & & Lab prepared & Cow urine distillate & 8 \\
\hline & & & Total & 48 \\
\hline
\end{tabular}


Table. 2 Details of poultry shops used in the experiment

\begin{tabular}{|c|c|c|c|}
\hline Sr. No. & Code & $\begin{array}{c}\text { No. of cow urine distillate } \\
\text { tested }\end{array}$ & No. of Replicates \\
\hline $\mathbf{1}$ & S 1 & 3 & 18 \\
\hline $\mathbf{2}$ & S 2 & 3 & 18 \\
\hline $\mathbf{3}$ & S 3 & 3 & 18 \\
\hline & Total & 9 & 54 \\
\hline
\end{tabular}

Table.3 Results of Phenol coefficient test of cow urine distillates against Staphylococcus aureus

\begin{tabular}{|c|c|c|}
\hline $\begin{array}{c}\text { Sr. } \\
\text { No. }\end{array}$ & Sample Code & $\begin{array}{c}\text { Phenol Coefficient } \\
\text { Mean } \mathbf{\pm} \text { SE }(\mathbf{n = 8})\end{array}$ \\
\hline $\mathbf{1}$ & C1 & NA \\
\hline $\mathbf{2}$ & C2 & NA \\
\hline $\mathbf{3}$ & C3 & NA \\
\hline $\mathbf{4}$ & C4 & $0.04 \pm 0.00$ \\
\hline $\mathbf{5}$ & C5 & $0.03 \pm 0.00$ \\
\hline $\mathbf{6}$ & P & NA \\
\hline
\end{tabular}

Table.4 Results of Phenol coefficient test of cow urine distillates against Escherichia coli

\begin{tabular}{|c|c|c|}
\hline Sr. No. & Sample Code & $\begin{array}{c}\text { Phenol Coefficient } \\
\text { Mean } \mathbf{\pm} \text { SE }(\mathbf{n}=8)\end{array}$ \\
\hline $\mathbf{1}$ & $\mathrm{C} 1$ & NA \\
\hline $\mathbf{2}$ & $\mathrm{C} 2$ & NA \\
\hline $\mathbf{3}$ & $\mathrm{C} 3$ & NA \\
\hline $\mathbf{4}$ & $\mathrm{C} 4$ & $0.04 \pm 0.00$ \\
\hline $\mathbf{5}$ & $\mathrm{C} 5$ & $0.03 \pm 0.00$ \\
\hline $\mathbf{6}$ & $\mathrm{P}$ & $\mathrm{NA}$ \\
\hline
\end{tabular}

NA- No Activity

Table.5 Results of in-vitro antimicrobial analysis of cow urine distillates

\begin{tabular}{|c|c|c|c|}
\hline \multirow{2}{*}{ Sr. No. } & \multirow{2}{*}{$\begin{array}{c}\text { Cow urine } \\
\text { distillate code }\end{array}$} & \multicolumn{2}{|c|}{$\begin{array}{c}\text { Zone of inhibition }(\text { Ømm) } \\
\text { Mean } \pm \text { SE }(\mathbf{n = 6})\end{array}$} \\
\cline { 3 - 4 } & & S. aureus & Escherichia coli \\
\hline $\mathbf{1}$ & $\mathrm{C} 1$ & ND & ND \\
\hline $\mathbf{2}$ & $\mathrm{C} 2$ & $\mathrm{ND}$ & ND \\
\hline $\mathbf{3}$ & $\mathrm{C} 3$ & $8.58 \pm 0.53$ & $3 \pm 1.91$ \\
\hline $\mathbf{4}$ & $\mathrm{C} 4$ & $18.55 \pm 0.45^{\mathrm{a}}$ & $15.21 \pm 0.82^{\mathrm{b}}$ \\
\hline $\mathbf{5}$ & $\mathrm{C} 5$ & $10.51 \pm 0.44^{\mathrm{b}}$ & $15.21 \pm 1.27^{\mathrm{b}}$ \\
\hline $\mathbf{6}$ & $\mathrm{P}$ & $\mathrm{ND}$ & ND \\
\hline
\end{tabular}

$\mathrm{a}-\mathrm{p}<0.01$

$\mathrm{b}-\mathrm{p}<0.05$

ND - Not detected 
Table.6 Evaluation of TVC counts of platform of poultry slaughter shop

\begin{tabular}{|c|c|c|c|}
\hline Sr. No. & Sample Code & $\begin{array}{c}\text { Pre-treatment } \\
\left(\begin{array}{c}\text { Average } \pm \text { SE) } \\
(\mathbf{n}=\mathbf{1 8}) \\
\mathbf{L o g}_{\mathbf{1 0}} \mathbf{c f u} / \mathbf{c m}^{\mathbf{2}}\end{array}\right.\end{array}$ & $\begin{array}{c}\text { Post Treatment } \\
\text { (Average } \pm \text { SE) } \\
(\mathbf{n}=\mathbf{1 8}) \\
\mathbf{L o g}_{\mathbf{1 0}} \mathbf{\mathbf { c f u }} / \mathbf{c m}^{\mathbf{2}}\end{array}$ \\
\hline $\mathbf{1}$ & $\mathrm{C} 3$ & $7.65 \pm 0.03$ & $7.49 \pm 0.03^{\mathrm{a}}$ \\
\hline $\mathbf{2}$ & $\mathrm{C} 4$ & $7.62 \pm 0.02$ & $7.23 \pm 0.04^{\mathrm{a}}$ \\
\hline $\mathbf{3}$ & $\mathrm{C} 5$ & $7.62 \pm 0.02$ & $7.33 \pm 0.03^{\mathrm{a}}$ \\
\hline
\end{tabular}

$\mathrm{a}-\mathrm{p}<0.01$

Table.7 Estimation of $S$. aureus counts of platform of poultry slaughter shop

\begin{tabular}{|c|c|c|c|}
\hline Sr. No. & Sample Code & $\begin{array}{c}\text { Pre-treatment } \\
\text { (Average } \pm \text { SE) } \\
(n=18) \\
\log _{10} \mathrm{cfu} / \mathrm{cm}^{2}\end{array}$ & $\begin{array}{c}\text { Post Treatment } \\
\text { (Average } \pm \text { SE) } \\
(\mathrm{n}=18) \\
\log _{10} \mathrm{cfu} / \mathrm{cm}^{2}\end{array}$ \\
\hline 1 & C3 & $7.00 \pm 0.09$ & $6.82 \pm 0.10$ \\
\hline 2 & $\mathrm{C} 4$ & $7.10 \pm 0.08$ & $6.63 \pm 0.13^{b}$ \\
\hline 3 & $\mathrm{C} 5$ & $7.20 \pm 0.03$ & $6.91 \pm 0.04^{b}$ \\
\hline
\end{tabular}

$\mathrm{b}-\mathrm{p}<0.05$

Table.8 Estimation of E. coli counts of platform of poultry slaughter shop

\begin{tabular}{|c|c|c|c|}
\hline Sr. No. & Sample Code & $\begin{array}{c}\text { Pre-treatment } \\
\text { (Average } \pm \text { SE) } \\
(n=18) \\
\log _{10} \mathrm{cfu} / \mathrm{cm}^{2}\end{array}$ & $\begin{array}{c}\text { Post Treatment } \\
\text { (Average } \pm \text { SE) } \\
(\mathrm{n}=18) \\
\log _{10} \mathrm{cfu} / \mathrm{cm}^{2}\end{array}$ \\
\hline 1 & C3 & $7.64 \pm 0.03$ & $7.49 \pm 0.03^{\mathrm{a}}$ \\
\hline 2 & $\mathrm{C} 4$ & $7.62 \pm 0.02$ & $7.24 \pm 0.03^{\mathrm{a}}$ \\
\hline 3 & $\mathrm{C} 5$ & $7.59 \pm 0.02$ & $7.32 \pm 0.04^{b}$ \\
\hline
\end{tabular}

$\mathrm{a}-\mathrm{p}<0.01$

b- $\mathrm{p}<0.05$

\section{Estimation of $S$. aureus counts}

The $S$. aureus counts of poultry slaughter platform were estimated by using VJ agar. The results are depicted in Table 7. All the three cow urine distillates were used in present experiment. The distillate C3 did not show any effect on $S$. aureus counts. The S. aureus are fairly resistant bacteria. The antimicrobial activity of the agent is dependent upon concentration and exposure time. A significant $(\mathrm{p}<0.05)$ reduction in $S$. aureus counts was observed in distillate $\mathrm{C} 4$ after treatment from $7.10 \pm 0.08 \log _{10} \mathrm{cfu} / \mathrm{cm}^{2}$ to $6.63 \pm 0.13 \log _{10} \mathrm{cfu} / \mathrm{cm}^{2}$, the reduction was from $7.20 \pm 0.03 \log _{10} \mathrm{cfu} / \mathrm{cm}^{2}$ to $6.91 \pm$ $0.04 \log _{10} \mathrm{cfu} / \mathrm{cm}^{2}$ in distillate $\mathrm{C} 5$. The results are in agreement with earlier workers (Jarald et al., 2008; Kalorey et al., 2009; Goswami and Kaushik, 2017). 


\section{Estimation of E. coli counts}

The E. coli counts were enumerated using EMB agar. The results are shown in Table 8. The distillate $\mathrm{C} 3$ pre-treatment $E$. coli counts were $7.63 \pm 0.03 \log _{10} \mathrm{cfu} / \mathrm{cm}^{2}$ pre-treatment reduced significantly $(\mathrm{p}<0.01)$ to $7.49 \pm 0.03$ $\log _{10} \mathrm{cfu} / \mathrm{cm}^{2}$. A highly significant $(\mathrm{p}<0.01)$ reduction in $E$. coli counts was observed after treatment of distillate $\mathrm{C} 4$. The pre-treatment E. coli counts were $7.62 \pm 0.02 \log _{10} \mathrm{cfu} / \mathrm{cm}^{2}$ which were reduced to $7.24 \pm 0.03 \log _{10}$ $\mathrm{cfu} / \mathrm{cm}^{2}$ in $\mathrm{C} 4$ treated group. In C5 treated group also highly significant $(\mathrm{p}<0.05)$ reduction of $E$. coli counts was observed.

Earlier many workers reported reduction of $E$. coli counts after treatment of cow urine distillates (Kekuda et al., 2010; Rajapandiyan et al., 2011; Ahuja et al., 2012). The results of present study are in agreement with earlier work.

Cow urine distillate (C3, C4 and C5) acts as bioenhancer of herbal extracts used as antimicrobial. Commercial cow urine distillates (C3, C4 and C5) inactivate $S$. aureus and E. coli in-vitro and in-vivo. Cow urine distillates (C3, C4 and C5) can be used as inactivating agent for maintenance of hygiene of slaughter platform in poultry slaughter house.

\section{References}

Ahuja, A., Kumar, P., Verma, A., and Tanwar, R.S., 2012. Antimicrobial activities of Cow urine against various bacterial strains. IJRAPR. 2(2): 84-87.

Association of Official Analytical Chemists (AOAC) 1997. 16th edn.3rd revision, Washington, U.S.A.

Bacteriological Analytical Manual 1998. 8th Edn. Prescribed by FDA, U. S.

Chauhan, R.S., and Dhama, K. 2010. Panchagavya (Cowpathy): An ancient wisdom and modern science. The Indian Cow Jan-Mar: 2-25.

Goswami, P. and Kaushik, U. 2017. Pharmacological Relevance of Cow urine against some pathogenic microbes. WJPPS. 6(8):1963:1968.

Gulhane, H., Nakanekar, A., Mahakal, N., Bhople, S. and Salunke, A. 2017. Gomutra (Cow urine): A multidimensional drug review article. IJRAP. 8(5).

Jangam, A.K. and Thali, P. WASP (Web Agri Stat Package) 2.0 Developed at ICAR Research Complex for Goa, Goa. 403 402.

Jarald, E., Edwin, S., Tiwari, V., Garg, R. and Toppo, E. 2008. Antioxidant and antimicrobial activities of Cow urine. GJP 2(2): 20-22.

Kalorey, D.R., Tumlam, U. and Warke, S. 2009. Modified Kamdhenu ark: curing of plasmid from mastitogen and synergistic action with antibiotics. J. Immunol Immunopathol. 11(1): 26-29.

Kaushik, R., Jain, J. and Rai, P. 2016. Therapeutic potentials of cow derived products. IJPSR. 7(4): 1383-1390.

Kekuda, Prashith, T.R., Nishanth, B.C., Praveen, K.S.V., Kamal, D., Sandeep, M. and Megharaj, H.K., (2010) Cow urine concentrate: A potent agent with antimicrobial and anthelminthic activity. JPR 3(5), 1025-1027.

Khanuja, S.P.S., Kumar, S., Shasany, A.K., Arya, J.S., Darokar, M.P., Singh, M., Sinha, P., Awasthi, S., Gupta, S.C., Gupta, V.K., Gupta, M.M., Verma, R.K., Agarwal, S., Mansinghka, S.B. and Dawle, S.B. 2002. Pharmaceutical composition containing cow urine distillate and an antibiotic. United States Patent. Patent no. US 6,410,059 B1. Date of Patent: 25/6/2002.

Koleci, X., Quinn, P.J., Çela, M. and Malaj, Z. 2007. The Place Of Disinfection In The Control Of Infectious Diseases. 
Albanian J Nat Tech Sci 12, 139-156.

Mandavgane, S.A., Rambhal, A.K. and Mude,

N.K. 2005. Development of cow urine based disinfectant. Natural Product Radiance. 4(5):410-412.

Minocheherhomji, F.P. and Vyas, B.M. 2014. Study of the Antimicrobial activity of Cow urine and medicinal plant extracts on pathogenic human microbial strains. IJAPBC. 3(4):836-840.

Mohanty, I., Senapati, M.R,, Jena, D. and Palai, S. 2014. Diversified uses of cow urine. Int J Pharm Pharm Sci. 6(3):2022.

Patterson, J.T. 1971. Microbiological assessment of surfaces. Journal Food Technology. 6, 63-72.

Poornima, G., Abhipsa, V., Rekha, C., Manasa, M. and Prashith Kekuda, T.R. 2012. Antibacterial activity of combination if Polyalthia longifolia Thw. Extract, Cow Urine Distillate and Streptomycin. Research J. Pharm. And Tech. 5(7):927-930.

Pradeep, K., Rao, J., Haribabu, Y., and Manjunath. 2014. Microbiological quality of meat collected from Municipal Slaughter houses and Retail Meat Shops from Hyderabad Karnataka Region, India. APCBEE 8: 364-369.

Rajapandiyan, K., Shanthi, S., Murugan, A.M., Alagu, Muthu, G. and Ranjit, S. A. J. A. 2011. Azadirachta indica - cow urine extract, a novel controlling agent towards clinically significant Multidrug resistant pathogens. JAPS. 01(10): 107113.

Randhawa, G.K. 2010. Cow urine distillate as bioenhancer. J. Ayurveda Integr. Med. 1(4): 240-241.

Ruehle, G.L.A and Brewer, C.M. 1931. United States Food and Drug Administration Methods of Testing Antiseptics and Disinfectants. Circular /U.S. Dept. of Agriculture- no.198.

Kishore, S.V., Rao, L., Ramesh, B. and Aditya, K. 2014. Indian Cow Urine Distillation and Therapeutic Uses. MJPMS. 4(1):1-5.

Sathasivam, A., Muthuselvam, M. and Rajendran, R. 2010. Antimicrobial activities of cow urine distillate against some clinical pathogens. GJP. 4(1):4144.

Taylor, J.H., Rogers, S.J and Holah, J.T. 1999. A comparison of the bactericidal efficacy of 18 disinfectants used in the food industry against Escherichia coli O157:H7 and Pseudomonas aeruginosa at 10 and $20^{\circ} \mathrm{C}$. JAM. 87, 718-725.

Varley, J.C., and Reddish, G.F. 1936. The phenol coefficient as a measure of the practical value of disinfectants. J. Bacteriol. 32(2): 215-25.

Zailani, S.A.Q., Bello, M., Raji, M.A., Kabir, J. and Yahuza, S.M. 2016. Microbial evaluation of meat contact surfaces in Red Meat Abattoirs of Bauchi State, North-Eastern Nigeria. OJMM 6:3-8.

\section{How to cite this article:}

Manjramkar, A.J., V.V. Deshmukh, R.N. Waghamare and Vaidya, M.S. 2019. Assessment of Antimicrobial Properties of Cow Urine Distillates. Int.J.Curr.Microbiol.App.Sci. 8(08): 25562565. doi: https://doi.org/10.20546/ijcmas.2019.808.297 